\title{
Rušení právních předpisů jako (staro)nový prvek ve správním soudnictví
}

\section{The Annulment of the Legislation as a Means to Reverting to the Old Approach in Administrative Justice}

\author{
Jiří Plachý*
}

\begin{abstract}
Abstrakt
Predmètný prüspèvek poukazuje na článek 87 Ústavy upravijici možnost qákonem prènést pravomoc rusit jiné právni predpisy nebo jejich jednotlivá ustanovení pro rozpor se zákonem z Ústavního soudu na Nejuyšši správni soud. Zmèna kompetence můře na jednu stranu dovršit prèdpoklad plně fungujicího samostatného správního soudnictví s podstatou a funkeci komplexni kontroly verejné správy, ale na straně drubé naráži na problematiku nastaveni zpissobu prezkeumu zákonnosti a ústavnosti u obou soudnich institucí. Cúlem je polemizovat s duisledky, keteré by tato żmèna prinnesla. Př̈spèvek se zamèruje na strèt kompetenci mezi

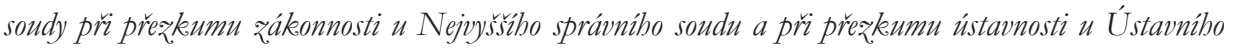
soudu v rámci rušeni toto:̌ného práuního prèdpisu.
\end{abstract}

\section{Klíčová slova}

Právni predpis; rozpor se zákonem; żmèna kompetence; prękum zákonnosti; prezkeum ústavnosti.

\begin{abstract}
The present contribution refers to the article no. 87 of the Constitution of the Czech Republic which governs the possibility to delegate jurisdiction to annul legal enactments other than statutes or individual provisions thereof if they are inconsistent with a statute to the Supreme Administrative Court instead of the Constitutional Court. On the one hand, the change of this competence can complete the assumption of a fully independent administrative justice with the nature and functions of complex control of public administration.

On the other hand, it faces problems in the way of setting the mechanism of review of the legality and the constitutionality by of both judicial institutions. The aim is to discuss about the implications that such a change would bring. This paper focuses on conflicts of competence between courts in reviewing of the legality by the Supreme Administrative Court and in reviewing the constitutionality by the Constitutional Court in relation to the same legal regulation.
\end{abstract}

\section{Keywords}

Legislation; the Law; Change of the Competence; Review of the Legality, Review of the Constitutionality.

\footnotetext{
* Mgr. Jiří Plachý, doktorand, Katedra správní vědy a správního práva, Právnická fakulta, Masarykova univerzita, Brno / Ph.D. student, Department of Administrative Studies and Administrative Law, Faculty of Law, Masaryk University, Brno, Czech Republic / E-mail: 257125@mail.muni.cz
} 


\section{Úvod}

Jednou z právních forem činností ve veřejné správě je vydávání normativních správních aktů $^{1}$ ve formě právních předpisư${ }^{2}$. Při jejich vydávání musí být dodržena zásada zákonnosti, která vychází z ústavního principu vázanosti veřejné moci zákonem. ${ }^{3}$ Dodržení této zásady je nezbytným předpokladem právní jistoty spojené s kontrolou ve veřejné správě prostřednictvím tzv. práuních záruk ve veřejné správě. ${ }^{4} \mathrm{~K}$ těmto zárukám se radí i kontrola veřejné správy ze strany moci soudní.

Soudní kontrola činnosti státu funguje jako efektivní ochrana práv vycházející z principu právního státu. ${ }^{5} \mathrm{~V}$ demokratickém právním státě je nezbytné zajistit kontrolu dodržování zákonnosti u vydaných abstraktních normativních správních aktů, která zajišt’uje legalitu aktů. Porušení zásady zákonnosti u právního předpisu je třeba chápat jako nezákonnost, která může vést ke zrušení aktu. $V$. Knapp správně poukazuje, „ř̌e nezákonným

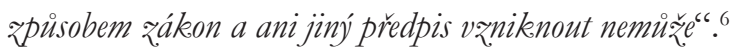

Možnost zrušit normativní správní akt svěřuje Ústava ${ }^{7} \mathrm{v}$ rámci soudní kontroly Ústavnímu soudu, který podle čl. 87 odst. 1 písm. b) rozhoduje o zrušení jiných právních předpisů nebo jejich jednotlivých ustanovení, jsou-li v rozporu s ústavním pořádkem nebo zákonem. Kontrola norem je v popředí samotného výkonu ústavního soudnictví a je pro Ústavní soud, vedle ústavních stížností, důležitou kompetencí. Ústavním přezkumem normativních aktů veřejné správy se vyrovnává dělba moci ve státě, dotváří se jednota právního řádu a jeho hierarchie, ve kterém platí, že normy vyšší právní síly jsou v souladu s normami nižší právní síly.

V čl. 87 odst. 3 písm. a) Ústava počítá s tím, že ,zákon mưže stanovit, že namisto Ústavního soudu rozhoduje o zrušeni práunich predpisu nebo jejich jednotlivých ustanovení, jsou-li v rozporu se zákonem, Nejuyšši správni soud." Běžný zákon může odejmout ústavně zaručenou pravomoc rušit právní předpisy Ústavnímu soudu a přidělit ji Nejvyššímu správnímu soudu.

1 O právotvorných či normativních správních aktech hovoří již $A$. Merkl jako o aktech, které jsou výkonem vyšší normy (zákona) vytvářející zároveň novou nižší normu, jejíž rozsah je užší než zákon (prováděcí předpis). Srov. MERKL, Adolf. Obecné právo správní. 2. část. Praha-Brno: Orbis, 1932, s. 3.

2 Pro účely tohoto článku se právními předpisy rozumí jiné právní předpisy, o jejichž zrušení rozhoduje Ústavní soud ve smyslu čl. 87 odst. 1 písm. b) Ústavy, zejména jsou jimi prováděcí právní předpisy; tj. nařízení vlády, vyhlášky ministerstev a ústředních správních úřadů, nařízení krajů a obcí. Rovněž právním předpisem jsou obecně závazné vyhlášky krajů a obcí. V teorii správního práva jsou označované jako „normativní správní akty“ nebo jako „nařízení“.

3 Srov. čl. 2 odst. 3 Ústavy a čl. 2 odst. 2 Listiny základních práv a svobod.

4 PRŮCHA, Petr. Správní právo, obecná ćást. 7. vyd. Brno: Masarykova univerzita, 2007, s. 319 a násl.

5 Srov. SEILER, Christian. Der einheitliche Parlamentsvorbehalt. Berlin: Duncker and Humblot, 2000, s. 73 a násl.

6 KNAPP, Viktor. Teorie práva. Praha: Nakladatelství C. H. Beck, 1995, s. 117.

7 Ústavní zákon č. 1/1993 Sb., Ústava České republiky, ve znění pozdějších předpisů. 
Jádrem článku je analytický a kritický pohled na situaci, pokud by na základě čl. 87 odst. 3 písm. a) Ústavy došlo $\mathrm{k}$ přesunu pravomoci rušit právní předpisy z Ústavního soudu na Nejvyšší správní soud (dále také jako „NSS“). Cílem tohoto článku je nejenom oživení diskuze na toto téma, ale zejména poukázání na praktické dopady, které s touto změnou kompetence úzce souvisí. Tento článek Ústavy zatím nebyl nikdy využit, ačkoliv tu určitá snaha byla. $\mathrm{V}$ důsledku toho zbyly některým právním odborníkům a teoretikům „oči pro pláč“. Inspirací k této polemice se stal odborný článek $V$. Mikuleho

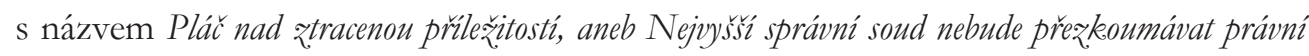
$p_{\text {redpisy }}{ }^{8}$, ve kterém je vyjádřena nespokojenost nad nesvěřením kompetence Nejvyššímu správnímu soudu rušit právní předpisy pro rozpor se zákonem. Měli bychom skutečně nad ztracenou př́ležitostí „plakat“? V následujících kapitolách budou vymezeny důvody, proč je, nebo není na místě „oplakávat“ tuto ztracenou př́ležitost. Úvaha o sjednocení kontroly činnosti orgánů veřejné správy pod správním soudnictvím možná podporuje využití zmiňovaného článku Ústavy. Otázkou je, zda bude skutečně dovršen předpoklad plně samostatného správního soudnictví s podstatou a funkcí nezávislého společenského kontrolního systému chránícího a zajišstujuícího uplatňování práva ve veřejné správě, pokud by došlo k přenesení kompetence na NSS. Je skutečně vhodné svěřit přesun pravomoci rušit právní předpisy z Ústavního soudu na Nejvyšší správní soud? Možnou odpověd’ lze nalézt v následujících kapitolách.

\section{Správní soudnictví a rušení právních předpisů}

Ústava upravuje působnost Nejvyššího správního soudu pouze omezeně v negativním vymezení „Nejvyšši soud je vrcholným soudním orgánem ve věcech patrǔcich do pravomoci soudù s víjimkou záležitostí, o nichž roz̧hoduje Ústavni soud nebo Nejvy šsi správni soud“.9 Jediný vztah Nejvyššího správního soudu vưči Ústavnímu soudu je vyjádřen ve zmiňovaném článku o přenesení pravomoci rušit právní předpisy na základě zákona. Ostatní principy organizace a působnost Nejvyššího správního soudu Ústava neřeší.

Přezkum správních aktů ve správním soudnictví naplňuje požadavek čl. 6 odst. 1 Úmluvy o ochraně lidských práv a základních svobod. ${ }^{10}$ Základ soudní kontroly ve sféře výkonu veřejné správy je blíže vymezen v čl. 36 odst. 2 Listiny ${ }^{11}$ jako kontrola v tzv. správním soudnictví. Podle V. Mikuleho se výrazem „správni soudnictvi“ označuje soudní kontrola veřejné správy, prričemž ve sféře soudnictví se jedná o nalézání práva ve věcech správních, tj. ve věcech

8 MIKULE, Vladimír. Pláč nad ztracenou př́ležitostí aneb Nejvyšší správní soud nebude přezkoumávat právní předpisy. Justiční praxe, 2002, č. 3.

9 Srov. Čl. 92 Ústavy.

10 Úmluva o ochraně lidských práv a základních svobod ve znění protokolů č. 3,5 a 8 , publikovaná pod č. 209/1992 Sb.

11 Usnesení předsednictva ČNR č. 2/1993 Sb., o vyhlášení Listiny základních práv a svobod jako součásti ústavního pořádku České republiky, ve znění pozdějších předpisů. 
příslušející jen veřejné správě. ${ }^{12}$ Výraz ,správni zcela jasně naznačuje, že tento druh soudnictví bude nalézat právo při realizaci výkonu moci v oblasti veřejné správy. Je otázkou názoru, zda do pravomoci správních soudů ve správním soudnictví má spadat, kromě dalších zákonem svěřených pravomocí1 ${ }^{13}$, rozhodování o všech věcech veřejné správy za účelem ochrany veřejných subjektivních práv při prrijímání rozhodnutí orgánů veřejné správy. Z vymezení pojmu $V$. Mikuleho by tomu tak být mělo a do činnosti tohoto typu soudnictví má spadat rovněž kontrola normativních správních aktů.

Při nesnadném formulování zavedení správního soudnictví do českého právního řádu zákonodárce zvolil koncepci obecných soudů a Nejvyššího správního soudu. S existencí Nejvyššího správního soudu počítala Ústava již od samého začátku a Nejvyššímu správnímu soudu svěrila v čl. 87 odst. 2 Ústavy $^{14}$ „, in eventum“ kontrolu zákonnosti právních předpisů nebo jejich jednotlivých ustanovení s oprávněním takový předpis zrušit pro rozpor se zákonem. Ústavní článek o rušení předpisů Nejvyšším správním soudem se do Ústavy dostal prostřednictvím pozměňovacího návrhu v Poslanecké sněmovně. Úmysl zákonodárce dělit pravomoc mezi soudy proto není vůbec odůvodněn, zvláště když správní soudnictví nebylo zcela v té době ještě koncipováno. $V$. Mikule nechce spekulovat o motivacích, které toto ustanovení vyvolaly, ale považuje za rozumné, aby problematiku rušení podzákonných právních předpisů přezkoumávaly správní soudy, jelikož svou povahou k tomu mají podstatně blíže, než Ústavní soud a odkazuje na v té době platnou úpravu Francie, Německa, Polska nebo Rakouska. ${ }^{15}$ Po vzoru těchto zemí mělo dojít k dovršení komplexního a samostatného výkonu správního soudnictví jako nezávislého společenského kontrolního systému chránícího a zajišt’ujícího uplatňování práva při dopadu výkonu veřejné správy. ${ }^{16}$ Správní soudy v těchto zemích disponovali oprávněním přezkumu platnosti právního předpisu nižší právní síly než zákon. Francouzská Státní rada prosadila, že kontrole budou podléhat akty nejvyšších orgánů výkonné moci. Pokud bychom vyslovili tezi, že do pravomoci správních soudů má spadat veškeré rozhodování o správních aktech orgánů veřejné správy za účelem ochrany veřejných subjektivních práv a vzali v potaz rozhodnutí Ústavního soudu o tom, že „Ústavní soud neni primárně povolán k. výkladu právnich predpisù v oblasti verejné správy, nýbrž ex constitutione k ochraně práv a svobod zaručených ústavnim porádkem. Pokud se týč výkladu podústavního práva,

12 MIKULE, Vladimír. In: HENDRYCH, Dušan et al. Sprámí právo. Obecná cáast. 8. vyd. Praha: C. H. Beck, 2012, s. 512.

13 Srov. \4 zák. č. 150/2002 Sb. soudní rád správní, ve znění pozdějších předpisů (dále jen „soudní řád správní").

14 V aktuálním znění Ústavy je ustanovení definováno v odstavci 3.

15 MIKULE, Vladimír. Pláč nad ztracenou př́ležitostí aneb Nejvyšší správní soud nebude přezkoumávat právní předpisy. Justični praxe, 2002, č. 3, s. 90.

16 PRŮCHA, Petr. Sprámí právo, obecná část. 7. vyd. Brno: Masarykova univerzita, 2007, s. 266. 
je právě Nejuyšsi správni soud tím orgánem, jemužp prísluši sjednocovat judikaturu správnich soudư “17, lze nabýt jednoznačného dojmu, že právě NSS je nejlépe vhodný k přezkumu abstraktních právních předpisů orgánů veřejné správy pro rozpor se zákonem. Podle $D$. Krysky má zákonodárce možnost výkon soudní kontroly veřejné správy svěřit přímo NSS, kterou nevyužil a naopak Ústavnímu soudu ponechal možnost napadnout ústavní stížností jakékoliv „zásahy“ orgánů veřejné správy do ústavně zaručených práv a svobod. ${ }^{18}$ Stojí poznamenat, že právní předpis může být v rozporu se zákonem a současně zasahovat do ústavně zaručených práv a svobod. Taková situace by mohla založit pravomoc pro oba soudy.

\section{Navržená kompetence pro NSS v soudním řádu správním}

V rámci příprav na zavedení fungování správního soudnictví v návrhu zákona o soudním řádu správním ${ }^{19}$ navrženo řízení nazvané „Soudní rízeni o àrušení právních prédpisù nebo jejich jednotlivých ustanoveni ${ }^{20}$ Zákonem tak měl být naplněn předpoklad stanovený článkem Ústavy a mělo dojít k přesunu rozhodování o rušení právních předpisů z Ústavního soudu na Nejvyšší správní soud. Tím mělo rušení právních předpisů definitivně spadat do pravomoci správního soudnictví za účelem naplnit jednotný a komplexní přezkum aktů veřejné správy.

V navrženém zákoně o soudním řízení správním byla řešena žalobní legitimace, definice účastníků řízení, náležitosti návrhu, nepřípustnost návrhu, náležitosti rozsudku a podmínky jeho prohlášení a vyhlášení. Předmětná procesní ustanovení se přebírala ze zákona o Ústavním soudu. ${ }^{21}$ Bylo stanoveno, že NSS řízení přeruší, pokud u Ústavního soudu probíhá řízení o zrušení téhož právního předpisu nebo zákona, s nímž je podle návrhu právní předpis v rozporu. NSS řízení rovněž přeruší a věc předloží Ústavnímu soudu, dospěje-li v řízení k závěru, že zákon nebo jeho jednotlivé ustanovení, s nímž je podle tvrzení návrhu právní předpis v rozporu, je sám v rozporu s Ústavou nebo ústavním zákonem. ${ }^{22}$ Ve zmiňované části návrhu zákona o soudním řádu správním měl Nejvyšší správní soud posuzovat soulad právního předpisu se zákonem a dbát nad dodržováním zásady zákonnosti. Právní předpis mohl NSS zrušit pouze pro rozpor se zákonem. V nastaveném modelu nemohlo dojít k úplnému přenesení kompetence zrušení, jelikož Ústavnímu soudu musí být stále zachováno posuzování ústavnosti právního předpisu.

17 Srov. nález Ústavního soudu ze dne 27. 11. 2008, sp. zn. III ÚS 2608/08.

18 KRYSKA, David. Srovnání českébo a polského správního soudnictví. Dizertační práce. Univerzita Karlova. Praha. 2012, s. 68. Publikováno také jako monografie. KRYSKA, David. Srovnáni českého a polského správního soudnictví. Praha: Univerzita Karlova, Právnická fakulta, 2013, 302 s.

19 Zákon č. 150/2002 Sb., soudní řád správní, ve znění pozdějších předpisů.

20 Sněmovní tisk č. 1080, vládní návrh soudního řádu správního. Poslanecká sněmovna, 3. volební období.

21 Zákon č. 182/1993 Sb., o Ústavním soudu, ve znění pozdějších předpisů.

22 Sněmovní tisk č. 1080, vládní návrh soudního řádu správního. Poslanecká sněmovna, 3. volební období. 
Uvedenému rozdvojení kompetencí mezi NSS a Ústavním soudem nejsou nakloněni J. Baxa a M. Maz̧anec, kteří poukazují na nejasné vymezení vztahů mezi oběma soudy. ${ }^{23}$ Rovněž poslanec Z. Koudelka byl proti přesunu kompetence z Ústavního soudu na NSS a na jeho návrh Ústavně právní výbor Poslanecké sněmovny novou kompetenci pro NSS navrhl zrušit. ${ }^{24}$ Část zákona upravující přesun kompetencí také neprošla politickými rozpravami v Poslanecké sněmovně a nebyla schválena. Pokud stále v Ústavě existuje čl. 87 odst. 3 písm. a), dává tím ústavodárce nadále najevo, že v budoucnu možná počítá dělením funkcí mezi soudy a nechává tuto možnost stále otevřenou. P. Prícha se domnívá, že je jen otázkou času a politické vůle, kdy jedna z dalších velkých novelizací soudního řádu správního tuto pravomoc NSS založí. ${ }^{25}$

\section{Problematické faktory $\mathrm{v}$ rozhodování: přezkum zákonnosti vs. přezkum ústavnosti}

Důvodem problematického přenesení kompetence je především v nastavení způsobu přezkumu zákonnosti a ústavnosti. Dále také podmínky a průběh soudního řízení a ostatní procesní a organizační otázky s řízením spojené. Těžko si představit situaci, kdy zákonodárce např́klad pouhým zmocněním v konkrétním zákoně pověři orgán výkonné moci (nap̌r. ministerstvo nebo vládu) k vytvoření prováděcího právního předpisu a zároveň v dalším ustanovení stejného zákona stanoví, že o případném zrušení prováděcího předpisu pro nezákonnost rozhodne Nejvyšší správní soud. Ústavní kautela by byla naplněna, jelikož zákonem by byla stanovena pravomoc NSS zrušit prováděcí právní předpis, ke kterému zákon zmocňuje, ale nebyl by už stanoven samotný proces soudního řízení rušení právních předpisů nebo jejich jednotlivých ustanovení.

V současném stávajícím modelu Ústavní soud provádí kontrolu dvojí, a to jak kontrolu ústavnosti, tj. zjištění souladu podzákonného právního předpisu s ústavním pořádkem, tak kontrolu zákonnosti, tj. kontrolu souladu právního předpisu se zákonem. Z obecného hlediska za daných okolností při přesunu pravomoci na NSS by měl totožný právní předpis posuzovat NSS z pohledu přezkumu zákonnosti a Ústavní soud z pohledu přezkumu ústavnosti. ${ }^{26}$ Subjekt podávající návrh na zrušení právního předpisu, by z důvodu právní jistoty mohl namítat nezákonnost u NSS a následně protiústavnost u Ústavního soudu. Přenesení kompetence na NSS ztrácí smysl při přednostním posuzování ústavnosti před zákonností. Pokud Ústavní soud zruší právní předpis pro rozpor s ústavními

23 BAXA, Josef a Michal MAZANEC. Reforma českého správního soudnictví. Právní rádce, 2002, č. 1, s. 9.

24 KOUDELKA, Zdeněk. Konkurence Ústavního a Nejvyššího správního soudu. In: HLOUŠEK, Vít a Vojtěch ŠIMÍČEK. Délba sondni moci v České republice. Brno: Masarykova univerzita, 2004, s. 80.

25 PRŮCHA, Petr. Základy správního práva: učebni text pro bakalárské studium. 1. vyd. Brno: Masarykova univerzita, 2016, s. 149.

26 Srov. např. MAZANEC, Michal. K úvahám nad záměry reformy správního soudnictví. Časopis pro právní vědu a praxi, 2000, č. 2, s. 225-234. 
zákony, Nejvyššímu správnímu soudu odpadá předmět řízení a řízení zastaví. Zamítne-li Ústavní soud návrh, pokračuje NSS v řízení. Tento postup prodlužuje řízení a dělená kompetence naráží na základní principy hospodárnosti a procesní ekonomie.

Pokud bude Ministerstvem vnitra v rámci dozorové pravomoci nad samostatnou působností obce podán návrh na zrušení obecně závazné vyhlášky obce pro rozpor se zákonem, který by posuzoval NSS, mohlo by se paralelně vést řízení u Ústavního soudu o přezkumu ústavnosti. Řízení před NSS by bylo přerušeno. Zruší-li Ústavní soud obecně závaznou vyhlášku obce pro rozpor s Ústavou, odpadl by důvod řízení před NSS. Celá věc může být komplikovanější, pokud nejdřív rozhodne NSS a teprve následně podá dotčený subjekt návrh Ústavnímu soudu, který zruší obecně závaznou vyhlášku pro rozpor s ústavním pořádkem. NSS by mohl tvrdit soulad se zákonem a Ústavní soud nesoulad s ústavností. To by odporovalo hierarchickému uspořádání jednotného právního řádu. Navíc Ústavní soud by mohl rozhodovat ještě o ústavní stížnosti proti nezákonnému zásahu. Obec totiž jako orgán územního samosprávního celku může využít oprávnění podat u Ústavního soudu „komunálni““ ústavní stížnost ve smyslu čl. 87 odst. 1 písm. c) Ústavy proti nezákonnému zásahu státu, zejména proti rozhodnutí Ministerstva vnitra o pozastavení účinnosti obecně závazné vyhlášky. ${ }^{27}$

Literatura k těmto otázkám zaujímá následující postoj. T. Langášeke uvádí, že zásahy státu do práva na samosprávu mohou mít nejrůznější podobu, nejčastěji půjde o realizaci dozorových a kontrolních oprávnění orgánů státu, zejména Ministerstva vnitra. ${ }^{28} \mathrm{Z}$. Koudelka konstatuje, že v př́padě zrušení obecně závazné vyhlášky ze strany NSS, by mohla územní samospráva podat tuto ústavní „komunální“ stížnost a dovolávat se zrušení rozhodnutí NSS z důvodu nezákonného zásahu státu s tvrzením, že postup byl ze strany soudu nezákonný. ${ }^{29}$ Zákon o Ústavním soudu ${ }^{30}$ uvádí, že pasivně legitimovaným v této ústavní stížnosti je státní orgán nebo jiný orgán veřejné moci, který přímo vydal napadené rozhodnutí. Typicky bude tímto účastníkem řízení např̀. obecný soud. ${ }^{31}$

K vydání prováděcích právních předpisů je zapotřebí zpravidla zmocnění obsažené v zákoně. ${ }^{32}$ Právní předpis vydaný na základě zákonného zmocnění musí být bezpodmínečně v mezích zákona. Podle P. Záreckeého termín „v mezích“ znamená, že žádný prováděcí

27 Srov. \123 zákona č. 128/2000 Sb., o obcích, ve znění pozdějších předpisů.

28 LANGÁŠEK, Tomáš. In: RYCHETSKÝ, Pavel, Tomáš LANGÁŠEK, Tomáš HERC, Petr MLSNA et al. Ústava Ceské republiky. Ústami zákon o bezpečnosti Ceské republiky. Komentár. Praha: Wolters Kluwer, 2015, s. 866.

29 KOUDELKA, op. cit., 2004, s. 82.

30 Srov. \ 76 odst. 1 zák. č. 182/1993 Sb., o Ústavním soudu, ve znění pozdějších předpisů.

31 ŠIMÍČEK, Vojtěch. In: FILIP, Jan, Pavel HOLLÄNDER a Vojtěch ŠIMÍČEK. Zákon o Ústavním soudu. 2. vyd. Praha: Nakladatelství C. H. Beck, 2007, s. 604.

32 Typicky u vyhlášek ministerstev a ústředních správních úřadů nebo nařízení obcí a krajů v přenesené působnosti. 
předpis nemůže upravit to, co neupravil samotný zákon. ${ }^{33}$ Jinými slovy prováděcí předpis může rozvést a konkretizovat pouze práva a povinnosti obsažené v zákoně. Je-li rozhodován soudní spor za užití právního předpisu a zákona, je soudce oprávněný posoudit soulad právního předpisu se zákonem podle čl. 95 Ústavy. Do posouzení spadá i formulace zákonného zmocnění, na základě něhož byl právní předpis vydán. Dojde-li soudce k závěru, že obsažené zákonné zmocnění je v rozporu s ústavním pořádkem, věc předloží Ústavnímu soudu. Ústavní soud zruší zákonné zmocnění a současně rozhodne o pozbytí platnosti prováděcích předpisư ${ }^{34}$ vydaných na základě protiústavního zákonného zmocnění. ${ }^{35}$ Opět zde může dojít k situaci, kdy soudce rozhodující o sporu přednostně využije Ústavní soud a předmět řízení o zrušení předpisu u NSS bude odvislý od rozhodnutí Ústavního soudu. Vezmeme-li například samotné vybočení z mezí zákona u prováděcího předpisu typu vyhlášky ministerstva, může se jednat o vybočení u právního předpisu z mezí zákonného zmocnění a současně založení i protiústavnosti pro rozpor s čl. 79 odst. 3 Ústavy, kdy orgány veřejné správy mohou na základě zákona a v jeho mezích vydávat právní předpisy. Pokud by došlo k dělení kompetencí, opět by tu byly dva soudy, které by se zabývaly totožnou problematikou. V. Mikule je přesvědčen, že primárně půjde o rozpor mezi zákonem a právním předpisem, tudíž by záležitost řešil Nejvyšší správní soud. Tento konflikt by podle něho jistě vyřešila judikatura Ústavního soudu, popř. nezbytná úprava zákona o Ústavním soudu. ${ }^{36}$ Jiná situace může nastat v případě, kdy zákonné zmocnění umožňuje upravit právním předpisem věci, které jsou výslovně vyhrazené zákonu. Tento předpis by byl oprávněn zrušit NSS, ale zrušit samotné zákonné zmocnění by spadalo do pravomoci Ústavního soudu. Ústavní soud by pak v této situaci zrušil i prováděcí předpisy vydané na základě nezákonného zmocnění.

Jestliže dojde k dělené pravomoci mezi soudy, vzniknou zcela určitě rozdílné odborné názory na problematiku a nepochybně i nekonzistentnost v rozhodování. Přenesení kompetencí na NSS může vést ke kompetenčním sporům mezi oběma soudy a k odlišné judikatuře, kdy stejný právní předpis bude posuzovat NSS z pohledu zákonnosti a Ústavní soud z pohledu přezkumu ústavnosti. ${ }^{37}$

Jádrem diskutovaného problému je, zda dělit mezi soudy kontrolu právních předpisů nebo kontrolu komplexně provádět pouze z jediného centra. Pokud bude kontrola

33 ZÁŘECKÝ, Pavel. Zákonná zmocnění pro vládu, ministerstva a jiné správní úǔady $\mathrm{k}$ vydávání prováděcích právních předpisů. Správni právo, 2007, č. 2, s. 66.

34 Srov. ust. \ 70 odst. 3 zákona č. 182/1993 Sb., o Ústavním soudu, ve znění pozdějších předpisů.

35 Bliže LANGÁŠEK Tomáš. In: RYCHETSKÝ, Pavel, Tomáš LANGÁŠEK, Tomáš HERC, Petr MLSNA et al. Ústava České republiky. Ústavni zákon o bezpečnosti České republiky. Komentár. Praha: Wolters Kluwer, a.s., 2015 , s. 889.

36 MIKULE, Vladimír. Pláč nad ztracenou př́ležitostí aneb Nejvyšší správní soud nebude přezkoumávat právní předpisy. Justični praxe, 2002, č. 3, s. 88.

37 Srov. např. MAZANEC, Michal. Reforma správního soudnictví v České republice. Soudní roz̧bledy, 2000, č. 8, s. 229-233. 
prováděna z jediného centra, a tato kompetence se hypoteticky svěří Nejvyššímu správnímu soudu, musel by NSS posuzovat soulad právního předpisu se zákonem a také s ústavním pořádkem. To zatím současná Ústava nepřipouští. Je otázkou, zda by bylo nutné, aby uvedené aspekty (zákonnost a ústavnost) byly oddělovány, jelikož pokud bude podzákonný předpis v rozporu se zákonem, bude zřejmě v rozporu i s Ústavou. Protiústavnost bude založena $\mathrm{v}$ př́padech, kdy podzákonný právní předpis bude ukládat povinnosti nad rámec zákona, ${ }^{38}$ nebo pokud pưjde o výhradu zákona pro výkon veřejné moci ${ }^{39}$. Je zřejmé, že NSS by se těmto otázkám nejspíš nevyhnul, proto by měly být tyto aspekty posuzovány v rámci jednoho přezkumu.

Stojí za to poznamenat, že Nejvyšší správní soud je způsobilý posoudit soulad s ústavním pořádkem, jak ostatně ukázal i v některých svých rozhodnutích. Za zmínku stojí rozhodnutí, ve kterém vycházel ze základního práva na spravedlivý proces podle čl. 36 Listiny a z prrímé aplikace citovaného ustanovení ústavního pořádku, kdy musel řešit situaci v konkrétním soudním řízení v souvislosti s přechodem nových práv a povinností z původního občanského soudního řádu na nový soudní rád správní. Soudní přezkum $\mathrm{v}$ daném prrípadě nebylo možné provést podle dřívější úpravy v občanském soudním řádu, nýbrž podle soudního řádu správního, ale přechodná ustanovení na uvedenou věc nepamatovala. S ohledem na princip denegatio iustitiae byla na místě aplikace ústavního pořádku, jelikož soud musel situaci, blíže neupravenou běžným zákonem, vyřešit ústavně konformně, aby umožnil přístup stěžovatelky k soudnímu přezkumu. Za situace, kdy není ústavní norma blíže provedena předpisem jednoduchého práva a nelze postupovat podle čl. 95 odst. 2 Ústavy, je jediným východiskem přímá aplikace ústavní normy. ${ }^{40}$ Lze vyslovit domněnku, že posuzování ústavnosti při rušení právních předpisů by NSS mohl, a nejspíš i dokázal, náležitě a kvalifikovaně posoudit.

V této souvislosti nelze opomenout, že NSS má své pravomoci v rozhodování o návrzích na zrušení opatření obecné povahy. NSS napadené opatření obecné povahy zruší, dojde-li k závěru, že je, mimo jiné, dán rozpor se zákonem. ${ }^{41}$ V. Sládeček s V. Tomozskovou hovoři o tom, že tato řízení jsou blízká rozhodování Ústavního soudu a opatření obecné povahy se svou povahou podzákonným právním předpisů značně přibližují. Konstatují, že „zpuisob prezkumu opatreni obecné povaby se procesně do značné míry podobá rozhodováni o návrhu na zrušeni zákona nebo jinébo právního predpisu“. ${ }^{42} \mathrm{O}$ tom, že opatření obecné povahy má blízko k právním předpisům podzákonného charakteru dokazuje fakt, že zákonodárce občas v zákoně nesprávně určí formu aktu, na základě které se následně regulují

\footnotetext{
38 Srov. čl. 4 odst. 1 Listiny.

39 Srov. čl. 2 odst. 3 Ústavy, resp. čl. 2 odst. 2 Listiny.

40 Rozsudek Nejvyššího správního soudu ze dne 20. 11. 2003, č. j. 2 Ads 40/2003-41.

41 Srov. ust. \101a a násl a \101d soudního rádu správního.

42 SLÁDEČEK, Vladimír. In: SLÁDEČEK, Vladimír, Veronika TOMOSZKOVÁ et al. Sprámní soudnictví v České republice ve vybraných státech Evropy. Praha: Wolters Kluwer ČR, a.s., 2010, s. 60 a 79.
} 
společenské vztahy v prováděcím předpise nebo v opatření obecné povahy. D. Hejč uvádí př́pady, kdy se v právní úpravě „vyskytuji taková zmocnèni k vydání zmocnèni k vydáni (z formálního blediska) opatreni obecné povahy, která jsou však ve skutečnosti (z materiálního hlediska) provádècím práunim prèdpisem“. ${ }^{43}$

Z. Koudelka v této souvislosti upozorňuje na jeden z důležitých procesních aspektů, a to, že při přenesení kompetencí by došlo na rozdílnost obsazení soudu. Ústavní soud ruší podzákonné právní předpisy v plénu, zatímco NSS podle stávající úpravy činil v senátech různých kolegií. Většina podzákonných předpisů by nejspíš patřila do obecného správního soudnictví a část z nich týkající se daní by př́slušela do kolegia finančního. ${ }^{44}$ Tento problém by mohl být vyřešen reorganizací NSS. Osazení soudu by mohlo být podobné jako v rrízení ve věci politických stran a věcech volebních, a to tak, že by se skládalo z předsedy a šesti soudců.

$\mathrm{S}$ přesunem této kompetence na NSS je na místě zvážit, zda by tím došlo $\mathrm{k}$ „odbřemeněni““ Ústavního soudu. Z. Koudelka uvádí, že k rozšíření pravomoci rušit podzákonné právní předpisy na NSS není důvod, protože počet těchto řízení u Ústavního soudu je z celkového počtu podání nepatrný, tudíž nemůže být řeč o „odbřemenění“. ${ }^{45}$ Předseda Ústavního soudu P. Rychetský již dříve v diskuzích obecně uvedl k celkovému nepřiměřenému nápadu u Ústavního soudu, že ,dokonce asi neni drubý ústavni sond v Evropé, k.terý by mél tak siroké kompetence jako my“. ${ }^{46}$ Z výroční zprávy Ústavního soudu za rok 2016 vyplývá, že počet návrhů na řízení o zrušení zákonů a jiných právních předpisů činil za rok 2016 celkem 24 oproti vysokému počtu ústavních stížností. ${ }^{47} \mathrm{~K}$,odbřemenění“ by nejspíš skutečně nedošlo.

\section{Závěr}

Cílem příspěvku bylo poukázat na zakotvení článku Ústavy upravující možnost přenést pravomoc rušit jiné právní předpisy pro nesoulad se zákonem z Ústavního soudu na Nejvyšší správní soud. Snahou bylo vyvodit možné důsledky pro oba soudy v rámci přezkumu zákonnosti a ústavnosti.

43 HEJČ, David. Smíšené správní akty v právním řádu ČR aneb 10 let účinnosti opatření obecné povahy. Právník, 2016, č. 10, s. 837.

44 KOUDELKA, op. cit., 2004, s. 81.

45 KOUDELKA, op. cit., 2004, s. 81.

46 Srov. BBC. Pavel Rychetský. Rozhovor pro BBC ze dne 6. 5. 2004. Dostupné z: http://www.bbc.co.uk/ czech/interview/story/2004/05/040506_rychetsky.shtml. Podobně v rozhovoru pro deník Právo ze dne 31. 10. 2003.

47 Srov. ÚSTAVNÍ SOUD. Ročenka Ústavního soudu 2016. Dostupné z: http://www.usoud.cz/fileadmin/ user_upload/ustavni_soud_www/Aktualne_prilohy/Ustavni_soud_Rocenka_2016_nahled.pdf 
S V. Mikulem lze souhlasit, že rušení právních předpisů se hodí spíše do správního soudnictví a znamenalo by to komplexní dovršení soudní kontroly veřejné správy. Tím by byl blíže a přesněji naplněn pojem, smysl a účel správního soudnictví.

Autor si ale není jistý, zda by uvedený argument obstál při změně kompetencí. Nejspíš nikoliv, zvláště pokud návrh zákona již v minulosti existoval a, v části obsahující rušení právních předpisů, nebyl schválen. V současné době nastavený model správního soudnictví plní předpoklad samostatného soudnictví i bez přiznané kompetence rušit právní předpisy.

Dělená pravomoc by přinesla komplikace v dělbě soudní moci. Argumenty právních teoretiků a odborníků vyznívají spíše v neprospěch přenesení těchto kompetencí na NSS. Ponechání současného stavu neznamená nenaplnění racionální dělby funkcí mezi oběma soudy ${ }^{48}$ a nemá vliv ani na účelnost, rozšíření, urychlení a zefektivnění přezkumu z dưvodu možného prohloubení principů demokratického právního státu. Dělená kompetence spíše naráží na princip hospodárnosti a procesní ekonomie. Ústavní soud svou roli plní dobře a není důvod rušení předpisů tříštit. K rušení právního předpisu u NSS by mohlo docházet pouze pro rozpor se zákonem a nikoliv pro rozpor s ústavním pořádkem, jelikož tuto kompetenci stále má a mít bude Ústavní soud. Možné kompetenční spory a rozdílné rozhodování mezi soudy neposílí funkci nezávislého společenského kontrolního systému zajišt'ující uplatnění práv ve veřejné správě. Pokud bude NSS svěřeno rozhodování i o ústavnosti, ztratí Ústavní soud jeden z výrazných atributů své pravomoci. Takový stav je nemyslitelný.

Pokud bychom uvažovali ve smyslu de constituone ferenda lze si představit přenesení celé pravomoci rušit právní předpisy na NSS z následujících důvodů. NSS již posuzuje návrhy na zrušení opatření obecné povahy, které jsou formou podobné právním předpisům a způsobem přezkumu se podobají přezkumu právních předpisů u Ústavního soudu. Dále NSS je schopen posoudit nejen zákonnost, ale rovněž ústavnost. Rovněž nelze spatřovat problém v obsazení soudu při rozhodování o zrušení právního předpisu. Přenosem pravomoci by nejspíš došlo k zamezení kompetenčních sporů a předešlo by se komplikaci v dělbě soudní moci.

Přesto současný stav rušení zákonů a jiných právních předpisů spadající do pravomoci Ústavního soudu má své odůvodnění a účel. Pro svoji komplexnost při posuzování zákonnosti a ústavnosti je právě Ústavní soud bezpochyby správnou institucí a z těchto důvodů není nutné nad ztracenou př́ležitostí pro Nejvyšší správní soud „plakat“.

48 PÍTROVÁ, Lenka. Nejvyšší správní soud - dárek k desetiletí české ústavy. In: KYSELA, Jan (usp.). Deset let Ústavy Ceské republiky. Východiska, stav, perspektivy. Praha: Eurolex Bohemia, 2003, s. 367. 